\title{
Dissecting the Perfect Storm: Law, Policy, and Violent African American Juveniles
}

Keywords: African American juveniles; Economic policies; War on drugs; Violence; Incarceration

\begin{abstract}
The African American male has been demonized in American Society. From an African American perspective the proof is in the pudding African Americans are only thirteen (13\%) of the U.S. population yet they make up fifty percent $(50 \%)$ of the adult prison population. Richard Pryorthe famousblack comedian once stated the following regard ing the CriminalJ ustice System and Afric an Americ ans: "Is it criminal justice or just us in the criminal justice system" [1]. The perfect stom can best be described as a series of individual events which by themselves are rarely harmful however when they come together they create a cataclysmic event. The African American community has faced many challenges in the U.S. however the series of events that it has not been able to overcome since the 1960s are: failed economic policies, the heroin epidemic of the 1960s and 1970s, the Crack Cocaine epidemic of the 1980s and 1990s, incarceration of adult black males (fathers), and the destruction of the two parent household in the Afric an American community. The end result of these policiescreated a void for African American juvenile male with many believing their only option is drugs and violence as a means of survival. This article explores theory, science, and provides some insight as to the complexity associated with African American male juveniles and violence in the Afric an American Community.
\end{abstract}

\section{Introduction}

For years society has been on a quest to rehabilitate criminals and yet the crime rate has consistently been on an ebb and flow. There is an expectation on our part that adults should be dealt with harshly and it is because of that the United States has done away with the concept of rehabilitation. Today the use of lengthy prison sentences are used to serve as a deterrent for those considering similar crimes. In addition, incapacitated is used as a form of prevention meaning if one is incarcerated they cannot commit crimes. This issue of rehabilitation left Martinson [2] pondering the following question: What Works? Martinson's response in an exhaustive in meta-analysis and literature review: Nothing really works when it comes to rehabilitating inmates. He later recanted and was of the belief that what works had to be individualized and it was costly.

If we were to examine Martinson's analysis it would appear that in order to prevent crime we should invest in intervention and prevention programs to impact crime. One community which appears to bear the brunt of failed policies in regards to the Criminal Justice System is the African American Community specifically African American males both adult and juvenile. Research indicates that there is a disparity in that African American males are more likely to have police contacts, be arrested, and sentenced receiving penalties which are much more severe than their white counterparts [3]. African Americans represent thirteen percent $(13 \%)$ of the total U.S. population yet they are fifty percent $(50 \%)$ of those incarcerated in adult facilities [4]. Associated

\section{Journal of} Forensic Investigation

\author{
David J. Thomas* \\ Department of Justice Studies, Florida Gulf Coast University, \\ Florida, USA \\ Address for Correspondence \\ David J. Thomas, Ph.D., LMHC Associate Professor, Justice Studies, \\ Florida Gulf Coast University, Florida, USA, Tel: (239) 590-7313; Fax: \\ (239) 590-7842; E-mail: dthomas@fgcu.edu \\ Submission: 16 April 2013 \\ Accepted: 31 May 2013 \\ Published: 03 June 2013
}

with Criminal Justice action are a series of stereotypes two (2) of the most noted are African American males are more than likely involved in the drug trade and/or they are violent. Are these stereotypes really true or have then been perpetuated by policy, media representations, and beliefs that one segment of society holds in relationship to another? Since this disparity exists do we understand why African American juvenile males are treated differently within the system and their cases are refereed at a rate twice that of their white counterparts? [5]

Even with the aforementioned data America likes to view itself as the hub for diversity and racial equality yet when it comes to treatment of African Americans in the Criminal Justice System which exhibits a bias. As you read this article reflect on these two hypotheses and choose the one that you believe to be most appropriate: The Criminal Justice System has an inherent racial bias in relationship to African American juvenile males and has a responsibility to correct the problems. Or the Criminal Justice System is fair and unbiased the reality is that African American males perpetrate more acts of violence and therefore should be prosecuted as such.

\section{Defining Juveniles and Data Limitations}

An acceptable definition of a juvenile is those individuals who have not reached the age of the majority which is eighteen (18). However, in some states age eighteen (18) is a magical number and when one is considered an adult meaning that they have all the rights and privileges of adults except consumption of alcohol. Yet the age of majority changes when a juvenile is involved in a crime. For example the state of Michigan considers eighteen (18) as the age of majority meaning that an eighteen (18) year old can purchase cigarettes legally, smoke legally, and vote [6]. However, when a juvenile commits a crime in the state of Michigan at the age of seventeen (17) they are considered an adult and will be tried as such [7]. For the purposes of this paper a juvenile is anyone under the age of eighteen(18).

In addition to the many different definitions of juveniles understand the data presented in this article is derived from government sources and as you review it understand that has limitations. No matter what data set we use there will be limitations to the data because participation is voluntary, data may be collected through surveys, or is self-report. With this in mind the information is only of data that is reported in some way and does not address crimes that are not reported. 


\section{Juvenile Population}

Howden and Meyer [8] note in the 2010 Census that the United States had a little more than seventy-four (74) million juveniles or twenty-four percent $(24 \%)$ of the U.S. population. For all crimes committed in 2009 juveniles were responsible for more than one (1) million crimes, sixty-thousand $(60,000)$ were violent crimes and one-hundred fifty-nine thousand $(150,000)$ were classified as other assaults. The remaining crimes are classified as property crimes or status offenses [9].

\section{African American Population}

Rastogi, Johnson, Hoeffel, and Drewery [10] offer in their analysis of the data obtained from the 2010 U.S. Census African American's are $12.6 \%$ of the U. S. population which translates into thirty-nine (39) million people (p. 8). Puzzanchera, Sladky, and Kang (2012) note that in the 2010 Census there were thirty-nine (39) million African Americans and of that thirty-nine (39) million five (5) million were juveniles between the ages of 10 and 17 (p. 6). Yet when it comes to involvement in violent crime and crime per se African American juvenile males continue to be disproportionately represented in the Criminal Justice System.

The Federal Bureau of Investigation (2012) reports that there has been a steady decline in violent crime from $2008-2010$ (p. 1). Although there has been a decrease in all crime Puzzanchera and Adams [5] note that in 2009 law enforcement officers arrested 2.11 million juveniles under the age of 18 which includes all crimes (p. 1). However, the most interesting data analyses is in the area of violent crimes committed by juveniles in 2009: they accounted for sixteen (16) percent of all violent crime arrests; the rate at which African American youths were arrested for murder as compared to their white counterparts was 7 to 1; African American males make up sixteen (16) percent of the juvenile population between the ages of 10 and 17 yet they accounted for forty-eight (48) percent of the juvenile violent crime outlined in the juvenile arrests of 2009 ( p. 8) [5].

\section{Literature Review}

For years there have been concerns regarding the disproportionate contact between the African American community and the Criminal Justice System as well as the overrepresentation within the juvenile and adult systems. Pope, Lovell, and Hsia [11] completed and exhaustive literature review and found that twenty-five (25) of thirty-four (34) studies examined highlighted that race determines if one will be processed or provided another avenue of resolution in the Juvenile Justice System. Pope et al. [11] argue that the data sets and research support the existence of disparities and bias within the juvenile justice system. Yet Pope et al are clear to point out that these disparities may be influenced by a number of other variables which has to be considered when analyzing data of this nature: inherent system bias; local policies and police practices; and social conditions that the system has no control of such as inequality, poverty, family, under or no employment, and performance in school.

In a similar study Huizenga, Thornberry, Knight, and Lovegrove [12] examined what they classify as disproportionate minority contact (DMC) of juveniles as opposed to an exhaustive literature review they analyzed data sets from three (3) programs: the Pittsburg Youth Study, the Rochester Youth Development Study, and the Seattle Social Development Project. Huizenga et al. argue that there is a definite disproportionally when it comes to arrest and detaining of African American male juveniles. However, they point out that there are a number of other variables which may dictate how an officer must proceed at the point of contact which means the decision may not be related to racial bias which are similar to those described by Pope et al.: the availability of a parent or responsible guardian for the youth if an officer wanted to counsel and release; arrest record of the juvenile and or the adult they are to be released to; a victim who is willing to press charges; the crime rate in a particular neighborhood; and the agency's strategies in response to a series of neighborhood problems or particular crimes (p. 42). Each of these variables individually or collectively may well influence if a juvenile will be processed or counseled and released.

In contrast, the National Center on Crime and Delinquency (NCCD) (2007) reports that there is a disparity by race when it comes to contact, arrest, referral and detention of African American juveniles. In fact, the NCCD supports and argues that African American juveniles are overrepresented in every category within the juvenile justice system. The NCCD provides the following data from the years 2002 to 2004 to support their argument: sixteen percent (16\% )of all the youth in the U.S. are African American; they account for twenty-eight percent ( $28 \%$ ) of all juvenile arrests; thirty percent (30\%) of all juvenile court referrals; they account for thirty-seven percent (37\% )of all juveniles detained; thirty-four percent (34\%) are formally processed in juvenile court; they account for thirty percent (30\%) of the juveniles adjudicated; account for thirty-five percent (35\%) of all juveniles waived to adult court; account for thirty-eight percent $(38 \%)$ of the youth in residential treatment; and fifty-eight percent $(58 \%)$ of youth admitted top adult prison (p. 3). In every category African American juveniles are twice as likely to be treated more harshly than their Caucasian counterparts based on the actual percentage of juveniles. Missing in the NCCDs research are the variables noted by Pope and Huizenga et al. Based on the data sets alone which hypothesis do you support: The Criminal Justice System has an inherent racial bias in relationship to African American juvenile males and has a responsibility to correct the problems. Or the Criminal Justice System is fair and unbiased African American males perpetrate more acts of violence and therefore should be prosecuted as such.

Many in the field of criminal justice will argue that free choice alone is the attribute which distinguishes man from other mammals and it is because of this we and we alone are responsible for our actions. However, to do so would negate what are offered in the fields of psychology, sociology, biology, and criminology. Each offers some paradigm or attempts to examine human behavior or actions in the context of interaction or cause and effect. Simply put we cannot judge ones actions in a vacuum and to evaluate an individual's criminal activity it should be assessed in the context of biological, psychological, and social influences or what is known as a biopsychosocial context to obtain a complete picture of their actions.

\section{Neuropsychology}

One of the many disciplines from which violent crime and aggression has been studied is the field of neuropsychology. Neuropsychology offers a link which provides a biological basis for violence and an explanation as to the cause and effect of the mind/ brain connection. Frontal Lobe Syndrome (FLS) is a mental disorder that offers a correlation between impulsive violence and frontal 
lobe damage. The frontal lobes are the focal point of memory, cognition, abstraction, concentration, and judgment. The clinical and empirical evidence linking impulsive violence to frontal lobe damage was significant enough to classify FLS as an organic mental disorder in the $9^{\text {th }}$ edition of the World Health Organization's International Classification of Diseases (ICD 9). The symptoms of FLS are an identifiable injury to the brain or a congenital defect. The manifestations of FLS include impairment of self-control, lack of foresight, loss of creativity, and spontaneity. Other deficiencies of Frontal Lobe Syndrome include increased irritability, selfishness, restlessness, lack of concern for others, boastfulness, and temper outbursts.

Feldman and Quenzer [13] conducted a study with rats to determine if impulsive violence is a byproduct of "nature or nurture." The results of the study were uniform. There were two groups of rats, those that were trained aggressively and those that were peaceably raised. The frontal lobe of one group of rats was intentionally damaged. When another rat was introduced into the experimental space of the rats with frontal lobe damage, the attacks were aggressive and described as abnormal. The rats kept biting and gnawing at their victims even after death. Pallone and Hennessy [14] take the interpretation of this data a step further and theorize that there is a short step between the frontal lobe damaged rat's unnatural activity and the crime scene of a sadistic murderer.

Pallone et al. conceptualized criminal aggression and have applied the term "Tender Box Theory." In developing this theory the authors collated the studies of adjudicated offenders reported in the past forty (40) years. Each of the offenders was evaluated by an accepted method of neurological examination through the use of an EEG, Lauria-Nebraska Instrument, or Reitan Instrument. Nineteen (19) offender groups were evaluated totaling 2100 subjects. The results of Pallone and Hennessy's study are remarkable and are quoted below:

Neuropathology is found in very high incidence among those offenders who have committed the most serious of aggressive offenses and among those whose offense histories reveal persistently aggressive patterns. At the extremes, the relative incidence of neuropathology among homicide offenders (94\%) exceeds the estimated incidence in the general population (3\%) at a ratio of nearly $32: 1$ or, phrased differently, the incidence of neuropathology among the murderers studied exceeds the estimated incidence in the general population by nearly $3200 \%$. Among the offenders studied, the mean incidence of neuropathology exceeds that in the general population by some 2033\%. (p.6)

The aforementioned concepts associated with FLS are interesting because if we examine a juvenile's behavior they are impulsive, show signs of increased irritability, selfishness, restlessness, lack of concern for others, and temper outbursts is how they act from birth and as they mature, learn and develop cognitively they learn to regulate their behavior. This happens without FLS but it is a maturing process. Meloy [15] classifies this behavior as affective meaning that it is immediate and in response to perceived threat or acting out of anger (p. 16).

However, there is a similar argument in relationship to juveniles in regards to acts of violence and poor decision making. It is recognized that juveniles know and understand the differences between right and wrong yet they continue to make poor decisions. Scott and Stenberg [16] argue that a juveniles emotional and psychological development lag behind their cognitive processes. It is because of this that society and the Criminal Justice System refuses to accept that a juveniles emotional and psychological processes do not mature at a rate which is equal to their cognitive processes. It is easy to understand the frustration of society as a whole when they view some of the acts of violence as heinous and reprehensible. The end result of such perceptions is the Criminal Justice System has been petitioning juveniles to be tried as adults in unprecedented numbers [17].

Any discussion regarding neuropsychology and the effects of brain damage to particular regions of the brain would be incomplete without a discussion of the most prominent neurotransmitters and their role in aggressive behavior. Neurotransmitter activity within the regions of the brain known as the prefrontal cortex modulates impulse control, sensation-seeking or novelty seeking, cognitive functions, and aggressiveness [18]. Then it follows that the lack of development to one or more of these systems may also predispose an individual to display impulsive violent behavior. The studies of neurotransmitters and aggression have focused on three (3) systems: The Serotonergic System and the neurotransmitter serotonin; The Dopamine System and the neurotransmitter dopamine; and The Norepinephrine System and the neurotransmitter norepinephrine, and their role in the modulation of impulse/aggressive behavior control. These neurotransmitters form the basis for information processing and communication within the brain and are considered neural forms of communication, which occur rapidly because they are released within the brain [18].

To support the aforementioned arguments Gur [19] notes that despite their size and/or appearance of juveniles' even teenagers are not mature cognitively and will reach maturity until they reach their mid-twenties. Gur describes the maturation process as peeling away layers of gray matter until the brain is fully matured. It is because of this that juveniles are easily influenced by peers or act spontaneously without fear of the consequences. Ultimately the decisions are made by the amygdala which is responsible for man's survival instinct and processing fear, anger, and pleasure. The frontal lobe provides balance or allows humans to process information and not act on impulse. Even in healthy normal juveniles there is a process of maturation which will impact their decision making until their mid-twenties [16].

The use of biology or genetics to explain violent crime or its causes creates fear and disdain in the African American Community. Detractors have labeled this research as "Scapegoat Biology," and asserted that this type of research has the potential to be racially biased. In October of 1992 the National Institute of Health (NIH) proposed a conference on the Genetic Factors in Crime, the African American Community and academia voiced such a negative opinion that the conference was canceled. The detractors believed that the outcomes of such research would be used to label African Americans as genetically predisposed to violent crime.

The fear and concern regarding this type of research is not without some justification, because of the many abuses perpetrated by Nazi Germany in World War II and even the U.S. Government with the Tuskegee Experiment. With that said the research has continued and the National Institute of Health held its first conference in 2011 which addressed DNA and crime. However, there is still a fear that this type of science may be used to target the poor and fail to address the crimes of the privileged [20]. 


\section{Sociological and Criminology}

The study of criminology is another of the many avenues that have looked to address the causes of crime and predict violent criminal behavior. Criminology's first attempts at explaining violent crime, its etiology, and identifying the criminal were biological in nature. In the $20^{\text {th }}$ century the focus changed to a sociological perspective and the role of biology was downplayed if not dismissed.

\section{Psychology}

If we were to examine every theory in psychology each would describe environmental conditions associated with a child's family and the love and nurturing one receives from the family unit. Three (3) theories which stand out and are interrelated are: Maslow's Hierarchy of Needs, Bowlbys' Attachment Theory, and Rothbart's Temperament Model because they explain the importance of a safe secure environment in the development of personality and temperament from birth. Safety and security provide a platform for a child to explore and learn through support and nurturing. Human beings are social creatures and failure to provide such an environment has a direct impact on their overall well-being. Bandura [21] argues that aggression is a learned behavior either through modeling or practice and that if not addressed through some form of control then it will be reinforced (p. 68).

\section{Genetics}

The first origins in understanding the criminal mind began in the Nineteenth $\left(19^{\text {th }}\right)$ century with the research of Ceasere Lombroso who is considered the father of Criminal Anthropology. Criminal Anthropology is defined as: "dealing with the natural history of the criminal, because it embraces his organic, psychic constitution, and social life just as anthropology does in the case of normal human beings and different races"( [22], p. 229).

Lombroso viewed cranial depressions found on the skulls of violent criminals as similar to those found on the skulls of primates whose development is primitive. These biological abnormalities were known as those belonging to an atavistic person, and such persons were noted to be born criminals. The second classification of minor law violators were known as criminaloids. Lombroso's theories set the stage for what is considered Modern Criminology [23].

The theories of Lombroso and other criminologist were the standard in the United States until the 1930s and today are viewed as being absurd and bordering on the ridiculous. Yet as a matter of practice in the United States twenty-seven (27) statesallowed forced sterilization of the mentally ill, feeble minded, and chronic offenders [24]. However, if we go back and examine the discussion of neuropsychology was Lombroso really so far off? Missing in the day of Lombroso was technology and even today scientists are still trying to unveil the mysteries of the human body and how they relate to crime.

\section{Body Type}

William Sheldon developed the theory of Somatotyping, which is another biological theory that is associated with identifying and predicting criminal behavior based on an individual's body type. Sheldon [25] argued that the body is an object, a tangible record, of the most long-standing and most deeply established habits that have been laid down during a long succession of generations.
Sheldon believed that there were three (3) distinct body forms called somatotypes. These body types could determine one's behavior and intelligence. The three (3) body types are: endomorph, the subject is soft and round; mesomorph, the subject is muscular; and ectomorph, the subject is tall and lean. The body type that was found to be involved in criminal activity most often was mesomorphic, as compared to a matched group of non-delinquents. Sheldon's earlier findings were supported in another study (Sheldon and Glueck, 1950) which was comprised of five-hundred (500) juvenile delinquents and non-delinquents.

Today this type of research would be described as junk science or as noted earlier as scapegoat biology. A final note regarding biology and its relationship to crime and intelligence Greenberg [26] reports that such studies were still in existence until the 1960s. In fact, freshmen that attended Ivy League and other prestigious colleges were required to pose for nude photographs from the 1940s to the 1960s. This was a direct result of Sheldon's research, which asserted that there was a relationship between body type and intelligence as well as other traits. The nude photographs of Hillary Rodham Clinton, George Bush, and Diane Sawyer are a part of Sheldon's historical archives, which are housed at the Smithsonian Institute. The photos and research have been sealed.

\section{Subculture Violence and the Code of the Streets}

It is here that criminological theories change and the focus becomes sociological in nature. In essence, criminology examines crime from a cause and effect perspective. One such perspective is known as The Chicago School of Criminology. It should be noted that this school provides a reader with many theories and principles in regards to the causes of crime, but none that identify criminals. In fact, there are so many theories that they alone could be the subject of an extensive literature review. The ideas of the Chicago School can be grouped into four (4) main headings: ecological theory, culture conflict, symbolic interactionism, and differential association. The prevailing premise from which the Chicago School operated is that crime is the result of social disorganization. The Chicago School is responsible for the methods developed in the study of crime and criminals including the use of official statistics, life histories, and ethnography. Of all the theories and sub-groupings noted in the Chicago School there is only one (1) which addresses the cause of violent crime and is known as the Subculture Violence Theory.

The subculture violence theory was introduced by Marvin Wolfgang and Franco Ferracuti in 1967 [27]. Central to the subculture violence theory is that violence has become an acceptable way of life for those who are disenfranchised by race and economics. This value system is contrary to middle class values and norms held by the majority of society.

This concept is supported by Thomas Hobbes and his theory of the social contract. Hobbes (as cited in Spurgeon Hall, Dennis, and Chipman [28] theorized that without government we would exist in a state of nature, which would consist of a life that is isolated, poor, nasty, brutish, and short. Hobbes further theorized that we are social creatures who need protection and seek to protect our property as well as our lives. In order to receive protection from the government we accept the social contract and in exchange give up free will and accept the values and norms of the middle class (pp. 111 - 115). If we accept that there is a social contract then one has to believe if the 
system fails then it may lead one to adopt the norms of a subculture which values violence over mainstream culture.

An extension of the subculture of violence theory was presented by Anderson in 1999 and it known as A Code of the Street which is a narrative ethnographic exploration of a low income African American neighborhood in the city of Philadelphia.The basis for Anderson's research was rather simple wanting to know why inner city youth are willing to perpetrate violence and/or acts of aggression toward each other (p. 90). Anderson [29] defines the code of the street as a set of informal rules which govern relationships, behavior, and specifically violence (p. 33). Interestingly, those who have adopted middle class values and live in these same communities have to adopt a duality in their personality one that allows them to address their contemporaries in the neighborhood and another which allows them to be accepted by mainstream America.

Anderson [29] argues that central to the code and the violence is being treated with respect and respect is described an external entity, "one that is hard-won, easily lost, and must constantly be guarded" (p. 31). The concept of respect and credibility is about safety and security and to be disrespected is a challenge to one's sovereignty. This need for self-preservation has grown out of distrust for police and the criminal justice system. This same code extends to the concept to "stop snitching campaigns" where those who have adopted the street code will resolve their own conflicts and are willing to die or kill for respect. Although Anderson's theory was applied to an African American neighborhood the very nature of the research model shows that it can be applied to any group because the focus is environment its impact on a child's developing personality.

\section{Case Study}

\section{Psychopath or code of the street}

You are a psychologist working in a local prison. You have a case load of 66 inmates who have been convicted of various crimes. It is time to update your files so you administer two tests the: Minnesota Multiphasic Personality Inventory (MMPI-2 Revised) and the Hare Psychopathy Checklist Revised (PCL-R). The MMPI will assist you in verifying your client's diagnosis and the PCL-R will assist you in determining if they are dangerous and a threat.

You have one client that stands out as being charismatic, knowledgeable, and great to interact with during sessions. His name is Mark Smith a 28 year old African American male. Mark is the first to take the tests. Before administering either exam you pull Mark's prison file and arrest record so you have some insight into his past criminal behavior. In examining the files Mark was convicted of murder at the age of 18 and had completed 10 of his original 20 year sentence. In addition, he received another 20 years for a murder that he committed while in prison. Finally, you dig deep into his criminal record and find that Mark committed his first murder at the age of 12 and was released from juvenile at the age of 16 in Washington D.C.

During the interview of the PCL-R Mark provides you with the following background. His mom and dad raised him but both were drug addicts hooked on heroin. When he was 10 years old drug dealers broke into his home killing his dad as Mark watched and they raped his mom making sure that Mark and his two siblings watched. The drug dealers told Mark this is what happens when you don't pay your bill. Mark states he understood that power and respect given to the drug dealers because they had money, guns, and people feared them. He began running drugs for the dealers that killed his dad and raped his mom. By doing this he was able to protect his mom and supply her habit as well as take care of his siblings.

\section{Case Study (Continued)}

\section{Psychopath or code of the street}

While working the corner Mark was robbed by another dealer. To exact revenge and regain his respect and credibility Mark found the dealer that robbed him and shot him in the head 5 times. Mark was convicted of murder spent 4 years in juvenile and was released into the custody of his aunt at age 16 . This was a new beginning and he moved to Florida and it is important to note while serving time in juvenile Mark's mother died of an overdose. Once in Florida Mark returned to his old habits and became a street dealer but moved up in the trade and had his own corner and runners. On a Friday he went to collect his money from one of his female dealers and she advised she did not have the money. He gave her until Monday to get the money and if she didn't have the money Mark told het that he would kill her. Mark arrived at the female's apartment at 5:00 pm on Monday when he entered the apartment her boyfriend was on the couch. The female's boyfriend reached for a gun and Mark shot and killed him. The female dealer ran from the apartment unharmed. Mark advised that he meant to kill her but did not.

Finally, while in prison Mark had a friend who asked for a loan so that he could purchase items from the prison commissary. The friend advised Mark that he would pay him in two weeks. The friend refused topay and became belligerent and irate when Mark asked for the money. Mark attacked his friend repeatedly pounding his head against the concrete floor until he was dead. Again you ask why and the response was the same: "If I let him live and continue to talk to me that way I would be a punk and everyone would try me. I did this because everyone here will respect me now".

You ask Mark: Is there anything that you did that you regret? Mark replies: "Yes there is, I regret that I allowed that bitch in Tampa to live. Had I killed her I would not be here today".

If you were to apply all of the research so far which hypothesis applies to Mark: The Criminal Justice System has an inherent racial bias in relationship to African American juvenile males and has a responsibility to correct the problems? Or the system is fair and unbiased African American males perpetrate more acts of violence and therefore should be prosecuted as such. Or would you argue that Mark's actions were free will and no matter his race he should be in prison. The theories are just that and none really apply he is a true psychopath.

In explaining the variables associated with juvenile violence there are many which have a profound influence on violent crime and juvenile and juvenile decision making. It is clear that a juvenile is who sixteen (16) or seventeen (17) years of age clearly knows the difference between right and wrong. However, research shows that their brains are not fully developed. The literature describes the maturation process as peeling away the layers of gray brain matter until a juvenile reaches their mid-twenties $[16,19]$. The research also shows that the quality of a child's environment from birth plays an 
essential role in personality development and temperament, yet void of a quality environment the child may develop a set of values which are contrary to mainstream society $[30,31]$. This is where the conflict begins between free will and survival. If respect and credibility are the only two (2) things that an individual values does it make sense that they adopt the code of the streets? The final pieces of this puzzle is an examination of the African American family, the Criminal justice System, and juvenile violence in the African American Community.

\section{The African American Family and the American Dream}

When we speak of the African American family traditionally it is believed that it was harmed or destroyed by slavery and never recovered which accounts for the number of single African American mothers in American society [32]. To counter the impact of this long held belief which was generated in a paper by New York Senator Daniel Patrick Moynihan and released by the Department of Labor researcher Herbert Gutman [33] released The Black family in Slavery and Freedom.

Gutman [33] determined although slaves were property for the most part they were able to maintain two (2) parent families. $\mathrm{He}$ also noted that after slavery the family unit was still two (2) parent families. Gutman [33] supports his hypothesis through a series of surveys of thirteen thousand $(13,000)$ African American families in Harlem, New York in 1925. The data obtained from the survey revealed the following: eighty-five percent $(85 \%)$ of the households contained two (2) parents; only thirty-two (32) of the 13,000 families were headed by a single mother under the age of thirty with three (3) or more children; seven to eight percent (7-8\%) of the females between ages twenty-five (24) and forty-four (44) were one parent households; twenty years earlier it was ten percent (10\%); three of four African American males over the age of forty-four (44) were unskilled laborers and were head of the two parent households; and five in six children lived with both parents (p. xix).

African Americans will argue that the federal government and the respected Senator Moynihan released such propaganda and misrepresentations of the facts to keep the African American population in a subservient role and perpetuate stereotypes and racism. Moynihan would argue that the purpose of the document was to detail injustice and provide a framework by which the United States can move forward and correct the mistakes of the past even though his data distorted the truth.

If slavery was not the demise of the African American family then what has had the greatest impact in the last fifty (50) years? The United States was heralded as the great industrial giant beginning with Henry Ford and the introduction of the Model $\mathrm{T}$ and mass production. However, the industry that built this country and supported the United States efforts during World War II began to crumble in the early 1970s with the oil embargo, gas shortages, soaring gas prices, poorly made automobiles, and Americans passion for foreign automobiles with excellent gas mileage. As factories began closing the United States moved away from industry and manufacturing and began investing in what we know now as a prison-industrial economy [34,35].

The elements of a prison industrial complex are: unskilled laborers lost their jobs, factories closed, and the economy crashed in those communities. Some communities, cities and states never recovered Detroit, Michigan is one such city that never recover. To offset the loss of jobs the prison industrial complex moved into communities replacing factories with prisons and jobs [34,35].

The end result was the beginning of the perfect storm which has lasted for decades. Item 1: The loss of jobs by unskilled laborers. Item 2: the influx of heroin in the Black community negatively impacted the African American family meaning that one or both parents were attracted to the drug trade in some fashion. Detroit is the perfect example of these two events colliding. Time magazine [36] reported the following: Detroit was in the midst of an all-out heroin war for control of the $\$ 350$ million heroin market; during this time there was an estimated 20,000 addicts in the city most of them black; and there was one homicide every four days associated with the heroin wars of Detroit (p. 20). In response to the heroin wars and rising crime rate the prison-industrial economy was introduced.

In the late 1970's heroin began to die out and powder cocaine became the drug of choice but was unavailable to the poor because of the price. Cooper [37] notes that because of the prices cartels and chemists began to experiment with various forms of cocaine and creating "Crack Cocaine" which would make it available to the masses and it quickly becoming the drug of choice in the African American community (pp. 27-28). Item 3: Crack was small, easy to conceal, cheap meaning that one could by a "piece or a rock" for as little as five dollars, and because it was a solid as opposed to powder it was smoked creating an instant feeling of euphoria and very addictive. The African American community transitioned from heroin to crack without missing a beat.

Item 4: With the introduction of heroin and later crack President Nixon declared a "War on Drugs". Presidents Nixon and Regan argued and believed that to interdict or eradicate the drugs was impossible so the most effective way to deal with the problem is to remove the customer and establish a zero tolerance policy with incarceration as the ultimate penalty for substance abuse [38]. This policy negatively impacted the African American family because the majority of the abusers of crack were in the African American community. Item 5: Incarcerating fathers and often times mothers destabilized a family foundation which was shaky at best. The victim(s) of their parent(s) incarceration were the children. The children's response to one or both parents incarceration were behavior related and described as: acting out, withdrawal, anxiousness, depression, anger, frustration, failure in school, and an increased likelihood of incarceration as a juvenile and adult $[35,39]$.

To further explain the cause an effect in the African American community Kirchhoff [34] notes that in the last few decades there has been a four-hundred percent (400\%) jump in incarcerations rates in the U.S. and at the end of 2008 there were 2.3 million adults incarcerated in state, local, or federal facilities with another 5.1 million on probation or parole (p. i). Prison growth has been fueled by the War on Drugs, lengthy prison sentences, minimum mandatory sentencing, and recidivism. Finally, data from the Bureau of Labor Statistics (2012) supports that the United States has moved from an industrial society to prison economy noting the following that there were approximately 770,00 people employed in the field of corrections in 2008 and that is expected to increase by five percent ( $5 \%$ ) by 2020 . It should be noted that the growth of corrections 
as an industry is slowing because the crime rates have been falling consistently over the past few years. However, probation and parole is expected to increase by eighteen percent (18\%) by 2020 (Bureau of Labor Statistics, 2012).

\section{Crack Cocaine and Weapons a Deadly Combination}

For years there has been a debate regarding the causes of violence in the African American community and the perpetrators. It is important to note that the African American community is one that does not willingly open its doors to outsiders or openly discuss its problems. Nor is it a community that has taken a stand to stop the violence and has criticized those who have attempted to bring the issue to the forefront [3]. To illustrate the seriousness of the problem Harms and Snyder [40] completed a meta-analysis of data and concluded that between the years 1980 and 1993 the juvenile homicide rate amongst African American juveniles from ages 12-17 increased one-hundred and sixty-three percent (163\%) (p. 1). This change in the homicide rate can best be described as sudden and the only new introduction to the African American Community was Crack Cocaine [41-43] determined that this rise is violence was dependent upon two variables crack cocaine and firearms. Independent of each other there may have been some rise in homicides but when placed together they became the driving force for the meteoric rise of homicides involving African American juvenile males.

There are several reasons why juveniles became the foot soldiers during the crack cocaine epidemic. In interviews conducted with suppliers many stated time and time again that juveniles are the perfect dealers because if they are arrested they will be released to their parents within 24-48 hours. If a juvenile is adjudicated (found guilty) and sent to a program the juvenile's sentence would be less than a year as long as it is not a crime of violence. Whereas adults could get up to twenty years or more depending on the type and amount of narcotics that they had in their possession at the time of their arrest. The incentives for juvenile involvement are many: money, power, guns, girls, and the ability to help their families who often times are on welfare. If we compare all of the perceived rewards as a juvenile drug dealer why would one want to work in a fast food restaurant or the local grocery store?

During my career as a law enforcement officer I have arrested and interviewed hundreds of juveniles for the sale and possession crack cocaine from 1992 to 1994 . The streets were so active at one point I made three-hundred (300) arrests of for the sale and possession of crack cocaine in a six (6) month period. Ninety percent $(90 \%)$ or 270 of those arrested were African American males under the age of 18. Many had been arrested multiple times on similar drug charges and as mentioned by the suppliers the juveniles were detained, adjudicated guilty, and released within 48 hours. The profile of each juvenile offender was similar: they lived in a single parent home where their mother was the sole provider; the family received welfare and lived at or below the poverty level; the child had no contact with their father or he was incarcerated; on average the juvenile had lived with two other sibling; they performed poorly in school and most had been labeled in school as Severely Emotionally Disturbed (SED); the SED classification is a designator for students with learning disabilities or behavior problems; SED students were assigned to special classes or an alternative school; they had multiple contacts with police in and out of school; with each arrest the juveniles became more aggressive and developed a since of invincibility because the juvenile justice system was considered an inconvenience; and many continued until they were either murdered, committed murder, or were arrested and received long prison terms as adults [44].

\section{The Paradigm}

There is an interesting debate and battle within the African American community as well as the law enforcement community regarding juveniles who commit violent crimes. Members of the African American community argue and fight that the problem is greater than the community and is one that can and should be considered a social issue. Police on the other hand have one way to respond to violence and that is to place those in jail who commit violent crime. If possible they will do whatever they can to prevent the acts of violence. However, based on the African American community's response to police past practices there is no trust.

Police will also argue that their job is not that of social service agency. However, law enforcements primary function is to serve the community and provide the services that a community demands and needs. Police are quick to note that in many instances when they arrest a juvenile that they have arrested the juvenile's mother, father, uncles, and aunts meaning the family values are contrary to society and criminal behavior is condoned and or rewarded. The police argument regarding the cycle of incarceration is supported by data from the Women's Prison Association and Home (n.d.): approximately 1.5 million children have parents behind bars; 10 million parents have been incarcerated at some point during their child's lives; one of every three African American males are under correctional supervision; children of offenders are five times more likely than their peers to go to prison; and one in ten will be incarcerated before they reach adulthood (p. 8).

For everything there is a cause and effect and our society has responded poorly in regards to change. There is an assumption that as industry changes we prepare our workers for the future. In fact, many of the unskilled jobs have been replaced by robotics assisting skilled laborers. In addition there is a belief has that every American has an equal opportunity to advance in this country. Nothing could be further from the truth the generation of African Americans who survived the Great Depression many never graduated from high school and had no choice but to take an unskilled manufacturing job to feed their families. This generation is one where many African American families lived at or below the poverty line and sent their children to failing schools throughout the United States. The goal for most of the children was to graduate high school and follow in their parents footsteps as unskilled laborers working in a factory. Manufacturing jobs were secure, provided decent pay, excellent benefits, and if they could last a pension after thirty (30) years.

\section{Conclusion}

I would love to say that the violence perpetrated by African American juveniles is the result of one issue or item. Some would argue everyone has to make a decision and that one's involvement in crime is a choice or a decision based on free will. As a researcher I will agree that free will is part of the equation yet I would have to ask: Are there any other factors which contribute to the choices a juvenile makes? From a scientific perspective one has to understand 
that no decision is made in a vacuum void of other variables. If you go back and review the case Mark Smith was he born a drug dealer and murderer? Or did he acquire that skill set because he saw that as an only option in order to survive and provide for his family?

The perfect storm can best be described as a series of individual events which by themselves are rarely harmful however when they come together they create a cataclysmic event. The African American community has faced many challenges in the U.S. however the series of events that it has not been able to overcome since the 1960s are: failed economic policies, the heroin epidemic of the 1960s and 1970s, the Crack Cocaine epidemic of the 1980s and 1990s, incarceration of adult black males (fathers), the destruction of the two parent household in the African American community. It's difficult enough with the aforementioned events influencing decision making not to mention a juvenile's emotional and psychological development lag behind their cognitive processes. In fact, each year of development until a juvenile reaches their mid-twenties the gray matter of the brain is described as peeling away the layers as they mature $[16,19]$.

The end result of these policies are African American juvenile males between the ages of $15-19$ are more likely to become victims of homicide by gun and are eight (8) times more likely than their White counterparts to die by firearm( [45], p. 4). It is clear that the introduction of Crack Cocaine alone is not responsible for these acts of violence it is the introduction of Crack Cocaine and the availability of guns [41-43].

The perfect storm is a road map. Based on the research each element of the perfect storm has been researched as an individual component however never collectively. Future policy considerations have to include addressing these as a group because if they continue to be addressed singularly the failed policies will remain as such. Finally, after reviewing all of the research which hypotheses have you chosen? The Criminal Justice System has an inherent racial bias in relationship to African American juvenile males and has a responsibility to correct the problems. Or the Criminal Justice System is fair and unbiased and African American males perpetrate more acts of violence and therefore should be prosecuted as such.

\section{References}

1. Pryor R (1975) Just us On Is It Something I Said [Medium of recording record]. Burbank, CA: Warner Brothers.

2. Martinson R (1974) What work? Questions and answers about prison reform The Public Interest 35: $22-54$.

3. Unnever JD, Gabbidon SL (2011) A theory of African American offending Race, racism and crime. New York, NY: Routledge.

4. Mauer M, King RS (2007) Uneven justice: State rates of incarceration by race and ethnicity. Washington D.C.: The Sentencing Project.

5. Puzzanchera C, Adams B (2011) Juvenile arrests 2009. Washington D. C Office of Juvenile Justice and Delinquency Prevention.

6. Michigan State Legislature (2011) Prohibited conduct by minor; violation as misdemeanor; penalty; participation in health promotion and risk reduction assessment program; costs; community service; exceptions; other violations. Lansing, MI: Michigan State Legislature.

7. Michigan State Legislature, 2. (2011) Probate code of 1939: Act 288 of 1939 Lansing, MI: Michigan State Legislature.

8. Howden LM, Meyer JA (2010) 2011 Age and sex composition. Washington D.C.: U.S. Census Bureau.
9. Federal Bureau of Investigation (2010) Crime in America: Uniform crime report. Washington D.C.: Department of Justice.

10. Rastogi S, Johnson TD, Hoeffel EM, Drewery MP (2011) The black population 2010.U.S. Census Bureau.

11. Pope CE, Lovell R, Hsia HI (2001) Disproportionate minority confinement: A review of the research literature from 1989 through 2001. Washington D. C: Office of Juvenile Justice and Delinquency Prevention.

12. Huizenga D, Thornberry T, Knight K, Lovegrove P (2007) Disproportionate minority contact in the juvenile justice system: A study of differential minority arrest/referral to court in three cities. Washington D. C: Office of Juvenile Justice and Delinquency Prevention.

13. Feldman RS, Quenzer LF (1985/1997) Fundamentals neuropsycho pharmacology. Washington, DC: American Psychological Association.

14. Pallone N, HennesseyJJ (1998) Brain dysfunction and criminal violence. Society, 35(6), 21-27.

15. Meloy JR (1998) The psychology of stalking: Clinical and forensic perspectives. In J.R. Meloy (Ed.) The Psychology of Stalking (pp. 2 -23). San Diego, CA: Academic Press.

16. Scott ES, Stenberg L (2008) Rethinking juvenile justice. Cambridge, MA: Harvard University Press.

17. Snyder HN, Sickmund M (1999) Juvenile offenders and victims: 1999 report Washington DC: Office of Juvenile Delinquency and Prevention.

18. Beaver KM, Walsh A (2011) The Ashgate research companion to biosocial theories of crime. Burlington, VT: Ashgate Publishing.

19. Gur RC (2004) Patterson v.Texas. Petition for Writ of Certiorari to US Supreme Court.

20. Cohen P (2011) Genetic basis of crime: A new look. The New York Times, p. C 1

21. Bandura A (1973) Aggression: A social learning process. Englewood Cliffs, N. J.: PrenticeHall.

22. Brown SE, Esbensen FA, Geis G (1998) Criminology: Explaining crime and its context ( $3^{\text {rd }}$ ed.). Cincinnati, $\mathrm{OH}$ : Anderson Publishing.

23. Lombroso C (2006) Criminal man (M. Gibson \& N. H. Rafter, Trans.). Durham, NC: Duke University Press. (Original work published 1876).

24. Laughlin HH (1912) Eugenical sterilization in the United States. Chicago, IL: Psychopathic Laboratory of the Municipal Court of Chicago.

25. Sheldon WH (1970) Varieties of delinquent youth. New York, NY: Hafner Publishing Company.

26. Greenberg B (1995) Nude posture studies of students create stir. The Johnson City Press, IA.

27. Wolfgang M, Ferracuti F (1967) The subculture of violence. London: Tavistock, Publications.

28. Spurgeon Hall RA, Dennis CB, Chipman TL (2000) The ethical foundations of criminal justice. Boca Raton, FL: CRC Press.

29. Anderson $E$ (1999) Code of the street: Decency, violence and the moral life of the inner city. New York, NY: W. W. Norton \& Company.

30. Bowlby J (1940) The influence of early environment in the development of neurosis and neurotic Character. The International Journal of Psychoanalysis 21: 154-178.

31. Rothbart MK (2007) Temperament, development, and personality. Current Directions in Psychological Science 16: 207-212.

32. Moynihan DP (1965) The Negro family: The case for national action. Washington D.C.: U.S. Department of Labor.

33. Gutman HG (1977) The black family in slavery and freedom, 1750-1925. New York, NY: Vintage Books.

34. Kirchhoff SM (2010) Economic impacts of prison growth. Washington D.C.: Congressional Research Service. 
Citation: Thomas DJ. Dissecting the Perfect Storm: Law, Policy, and Violent African American Juveniles. J Forensic Investigation. $2013 ; 1$ (1): 9.

ISSN: 2330-0396

35. Wildeman C, Western B (2010) Incarceration in fragile families. Future of Ou Children 20: 157-177

36. (1971) Heroin shooting war. Time Magazine 97: 20.

37. Cooper EF (2002) The emergence of crack cocaine abuse. Hauppauge, NY Novinka Books.

38. Rosenberger LR (1996) America's Drug War Debacle. Brookfield, VT Ashgate Publishing.

39. Gibson DD (2008) The impact of parental incarceration on African American families. Praxis 8: 23-29.

40. Harms PD, Snyder HN (2004) Trends in murder in juveniles: 1980-2000 Washington D.C.: Office of Juvenile Justice and Delinquency.
41. Blumstein A (1995) Youth violence, guns, and the illicit-drug industry. J Crim Law Criminol 86: 10-36

42. Grogger J, Willis M (1998) The introduction of crack cocaine and the rise of urban crime rates. Cambridge, MA: National Bureau of Economic Research.

43. Cork D (1999) Examining space: Time interaction in city-level homicide data: Crack markets and the diffusion of guns among youth. J Quant Criminol 15: 379-406.

44. Thomas D (2013) Review of drug arrest case files 1992-1994 Gainesville Police Department Unpublished raw data.

45. Children's Defense Fund (2012) Protect children, not guns 2012. Washington D.C.: Author. 